\title{
ITK wt Allele
}

National Cancer Institute

\section{Source}

National Cancer Institute. ITK wt Allele. NCI Thesaurus. Code C51081.

Human ITK wild-type allele is located within 5q31-q32 and is approximately $74 \mathrm{~kb}$ in length. This allele, which encodes tyrosine-protein kinase ITK/TSK protein, plays a role in signal transduction. 